\title{
Professor Marek Sznajderman: one of the founding fathers of Polish science of arterial hypertension
}

\author{
Tomasz Pasierski ${ }^{1}$, Andrzej Januszewicz² \\ 1 Medical University of Warsaw, Warsaw, Poland \\ 2 National Institute of Cardiology, Warsaw, Poland
}

Correspondence to: Prof. Tomasz Pasierski, MD, PhD, Department of Medical Ethics and Palliative Medicine, Medical University of Warsaw, ul. Litewska 14a, 00-581 Warszawa, Poland, phone: +48221169234 , email: tpasierski@wum.edu.pl Received: August 27, 2020. Accepted: August 28, 2020. Published online:

September 25, 2020. Kardiol Pol. 2020; 78 (9): 952-953 doi:10.33963/KP.15614 Copyright by the Author(s), 2020
Professor Marek Sznajderman, a distinguished Polish cardiologist, passed away on August 15, 2020. He was born in Warsaw in 1929. His father, Ignacy Sznajderman, was a well-known Warsaw neurologist and an assistant in the nervous diseases ward at the Jewish Hospital in Czyste, Poland. Professor Sznajderman's family were victims of the Holocaust. He survived the liquidation of the Warsaw Ghetto. His his mother was killed during the 1941 pogrom in Złoczów and his younger brother and father were killed in the Treblinka extermination camp. He was a prisoner of, among others, Majdanek and Auschwitz extermination camps, and managed to escape from the "Death March."

Professor Sznajderman graduated from the Faculty of Medicine of the University of Warsaw in 1952. In the same year, he started his medical internship at the Second Clinic of Internal Medicine of the Medical Academy in Warsaw.

An important stage of his scientific work was his scholarship at the Royal Infirmary in Edinburgh, Great Britain, in a world-renowned hypertension research center headed by Professor Michael Oliver. Between 1953 and 1954, he worked as a doctor in the Polish team of the Military Hospital No. 41 in North Korea.

In his early research conducted together with Włodzimierz Januszewicz, Bożenna Wocial, and Małgorzata Ciświcka-Sznajderman, he focused on the involvement of catecholamines and metabolic disorders in myocardial infarction. This research team showed for the first time an increase in noradrenaline and adrenaline concentrations in acute phases of myocardial infarction. His further research centered around the role of catecholamines in the pathogenesis of primary

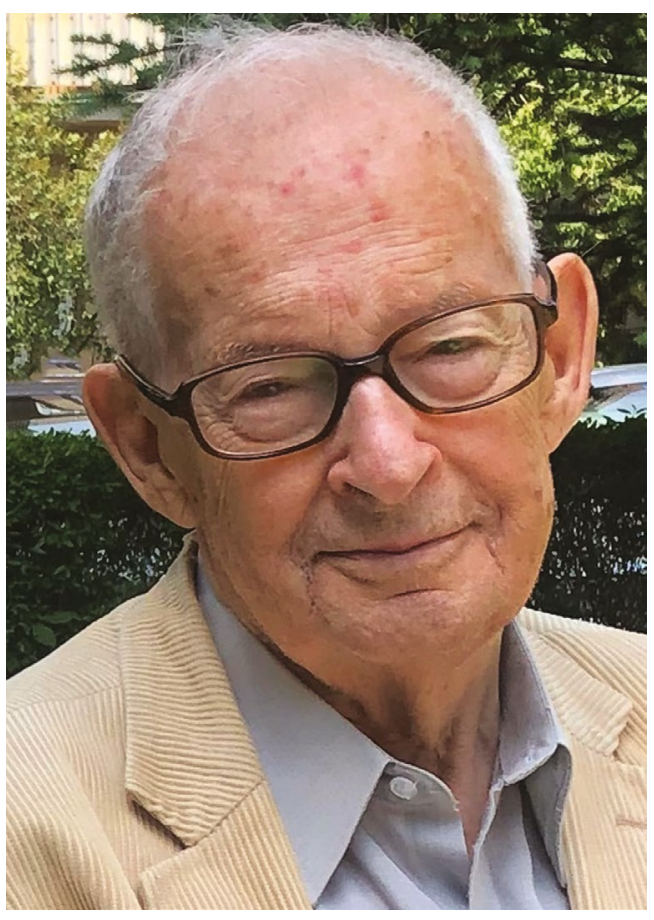

FIGURE 1 Professor Marek Sznajderman in 2020 (photo from family archives)

and secondary hypertension, and especially in the pathogenesis of pheochromocytoma.

The monograph entitled Hypertension, published in Poland in 1970, was a great achievement of Włodzimierz Januszewicz and Marek Sznajderman. This work constituted the most comprehensive contemporary monograph on arterial hypertension published not only in Poland but also in Europe. 
In the following years, Professor Sznajderman coauthored with Włodzimierz Januszewicz and Bożenna Wocial a monograph entitled Pheochromocytoma, and then, together with Włodzimierz Januszewicz, Henryk Chlebus, and Bożenna Wocial, a monograph entitled Catecholamines.

Professor Sznajderman was the secretary of the Editorial Office of Kardiologia Polska (Kardiol Pol, Polish Heart Journal) from 1968 to 1980, and from 1983 to 1990, he was the editor-in-chief of the journal.

In 1981, he was appointed the chairman of the Department of Hypertension in the newly established Institute of Cardiology in Warsaw. One of his greatest achievements was the creation of a modern department from the ground up, which became one of the leading Polish hypertension referral and research centers.

Professor Sznajderman carried out a wide array of research projects on many aspects of hypertension, for example, its secondary forms, the effects of new hypotensive drugs, and 24-hour arterial blood pressure monitoring. He also created a team of excellent well-educated physicians, 3 of whom received a post-doctoral degree and 10 , a doctor of medical sciences degree.

Professor Sznajderman was a Honorary Member of the Polish Society of Cardiology, Polish Society of Internal Medicine, British Society of Cardiology. He made a great contribution to the establishment and development of the Polish Society of Hypertension, which he also cofounded.

He was an excellent and gifted doctor who brought together comprehensive education and sensitivity as well as insight, which gave him the great ability to establish an accurate diagnosis at the patient's bedside. Professor Sznajderman was a person of extraordinary character who could combine integrity with openness and kindness to people.

He was a person of great intellect, which was reflected not only in the always accurately formulated thoughts that he could pour on paper with ease, but also in his love for music and literature. Moreover, he showed this quality with a subtle sense of humor.

Professor Sznajderman will remain in our memory as a man of great personality and as an outstanding physician.

\section{SUPPLEMENTARY MATERIAL}

The Polish version of the text is available at www.mp.pl/kardiologiapolska.

\section{ARTICLE INFORMATION}

CONFLICT OF INTEREST None declared.

OPEN ACCESS This is an Open Access article distributed under the terms of the Creative Commons Attribution-NonCommercial-NoDerivatives $4.0 \mathrm{In}$ ternational License (CC BY-NC-ND 4.0), allowing third parties to download articles and share them with others, provided the original work is properly cited, not changed in any way, distributed under the same license, and used for noncommercial purposes only. For commercial use, please contact the journal office at kardiologiapolska@ptkardio.pl.
HOW TO CITE Pasierski T, Januszewicz A. Professor Marek Sznajderman: one of the founding fathers of Polish science of arterial hypertension. Kardiol Pol. 2020; 78: 952-953. doi:10.33963/KP.15614 